\title{
Who's to Blame for the Money Drain? : Corporate Power and Corruption as Competing Narratives for Lost Resources
}

\author{
Ylönen, Matti Ville Samuli \\ Oxford University Press \\ 2019-05
}

Ylönen , M V S 2019 , Who's to Blame for the Money Drain? Corporate Power and

Corruption as Competing Narratives for Lost Resources . in P G Alston \& N R Reisch (eds),

Tax, Inequality, and Human Rights . , 16 , Oxford University Press . https://doi.org/10.1093/oso/9780190882228.003

http://hdl.handle.net/10138/329573

https://doi.org/10.1093/oso/9780190882228.003.0017

unspecified

acceptedVersion

Downloaded from Helda, University of Helsinki institutional repository.

This is an electronic reprint of the original article.

This reprint may differ from the original in pagination and typographic detail.

Please cite the original version. 


\title{
Who's to Blame for the Money Drain? Corporate Power and Corruption as Competing Narratives for Lost Resources
}

\author{
MATTI YLÖNEN
}

\section{Introduction}

Fighting corruption has been one of the most prominent goals of development policy since the late 1990s. However, the emergence of an anti-corruption agenda was not the result of a particular increase in corruption at that time, but rather was the result of a multitude of political forces and a shift in the development policy thinking. One important factor that enabled the rise of the anti-corruption agenda was the demise of the analytical and policy framework focusing on corporate power over states, which was championed by the United Nations Centre for Transnational Corporations (UNCTC) in the 1970s. The UNCTC was an independent research center that operated from 1975 to 1993 with a mandate to study the role of large corporations in developing countries. Its project faced severe hardships in the 1980s amidst the changing political and intellectual climate, resulting in the destruction of its epistemic community and ultimately the dissolution of the UNCTC in 1993. I maintain that the resulting intellectual vacuum created an environment that supported analyses and policy frameworks focused on the role of public sector corruption in developing countries.

One result of these dynamics was that the development policy community largely ignored the of the "pinstripe infrastructure" of financial intermediaries, professions and tax havens in corruption for more than two decades. It was only with the rise of the tax justice agenda in the 2000s that corruption watchdogs began to recognize these drivers of corruption. However, this awakening has remained half-hearted, as most of the discussions on corruption still focus solely on public officials and politicians. I argue that understanding these broader ideational shifts are highly relevant also for the human rights agenda. The ways we explain 
why and how developing countries are losing the resources needed to fulfill human rights obligations can have a huge impact on the policy responses that aim to support the fulfillment of human rights. In particular, it is not enough to demand that states construct wellfunctioning tax systems in order to fulfill their human rights obligations. Rather, equal attention should be paid to the international structures that sustain the corporate power that enables the international tax flight. However, our current conceptions of business and human rights do not put enough emphasis on the structural powers of large corporations over developing countries. This issue needs more attention.

The rest of this chapter progresses as follows. In the next section, I discuss the role of narratives behind national development policies, and introduce the aforementioned two paradigms. Section three discusses in more detail the evolution and contributions of the corporate power and corporate planning frameworks that the UNCTC developed, especially in the $1970 s^{2}$ In the fourth section, I analyze the emergence and evolution of the anticorruption development agenda, especially from the 1990s onward. The penultimate section discusses the reasons behind the demise of the UNCTC's corporate power agenda and how its oblivion created political space for the emergence of the anti-corruption agenda and narrative. In addition, this section focuses on the challenges that the tax justice movement and the emerging tax justice policy agenda have managed to pose to the prevailing anticorruption framework. Finally, the last section discusses the implications for further research.

\section{Two Narratives About Lost Resources}

We need narratives to explain how certain societal problems have arisen and why they persist, and to offer hope by indicating what could be done to solve the perceived problems. In reality, societal problems are typically multifaceted and any attempt to explain them using a single narrative is likely doomed to failure. At any given point in time, however, only one 
or at best a few narratives can reach paradigmatic status ${ }^{3}$ and act as a beacon for policy makers. What is more, these paradigmatic policy narratives often inspire researchers, resulting in a body of research that comments on or draws from the currently dominant narratives. This can create a self-enforcing cycle where attention begets more attention. During this process, competing theories and historical precedents may be forgotten.

Depending on one's individual perspective, the role of narratives in development can be an extremely broad topic. In order to tackle this challenge, my particular focus is on narratives that center on misuse of resources that should have been directed to people in need. Therefore, I will not focus very much on questions that ask if the international trade system is just or unjust, what should be done regarding the debt problems of developing countries, or what cultural or social factors may be at work in developing countries. Rather, I focus first on the narrative that identifies corporate malpractice as a reason for the domestic resource drain, and second on the narrative that puts the blame on corrupted civil servants and politicians of developing countries. I will argue that the triumph of the latter narrative is closely connected with the emergence of the human rights agenda as the underlying framework of the anticorruption efforts.

Balakrishnan Rajagopal has noted how "human rights and corruption discourses constitute, as it were, the two sides of the legitimacy coin, and that both have the same intellectual pedigree. ${ }^{״ 4}$ Citing examples from Transparency International and other anticorruption organizations, Rajagopal argues that according to the "view of the corruptionhuman rights dialectic, both are seen as external to each other in some way, having quite autonomous existences, in a relationship of a sort of inverse proportion: as corruption goes up, human rights comes down." The corruption discourse "performs the crucial task of restoring faith in the western ideals of liberal democracy, rule of law, and development."6 Should the corruption problem be solved, "the belief goes, development would benefit all, 
everyone would enjoy rights, rule of law would flourish, and democracy would actually constrain power." ${ }^{\prime 7}$ While this may be a provocative conclusion, it does contain a significant seed of truth.

I will argue that the anti-corruption narrative must be re-invented in order for it to remain relevant, and that understanding these dynamics are also important for the efforts to establish linkage between taxes and human rights. Despite decades of relentless anticorruption work by development agencies, the underlying problems have not been solved. Even more importantly, the anti-corruption paradigm has failed to tackle the issues of revenue loss and tax flight. Tax justice advocates have argued that the cost of "traditional" domestic corruption, attributable to public sector actors, pales in comparison to the resources lost due to tax avoidance and profit shifting by large international enterprises when illicit financial flows from developing countries are considered. ${ }^{8}$ Moreover, tax justice campaigners have also argued that this state of affairs is fueled by tax rules imposed by rich countries and enabled by financial intermediaries and secrecy jurisdictions that often operate with tacit or explicit support from many of the world's richest countries. ${ }^{9}$ Partly as a result of these developments, researchers have pointed out that Sub-Saharan African countries can actually be seen as net creditors to the rest of the world, when capital flight is taken into account. ${ }^{10}$

Tax justice campaigns have at least in some extent reinstated the focus on corporate power over states in tax matters. This has forced anti-corruption campaigners to recognize that the tax planning power of large corporations is a serious issue, which affects the international anti-corruption agenda. After this realization, it is difficult to imagine how the anti-corruption agenda can survive in the form that James Wolfensohn, then the President of the World Bank Group, defined it in his iconic 1996 and 1997 addresses to the Bank's annual meetings. In 1996, Wolfensohn set the agenda by stating, "[L]et's not mince words: we need 
to deal with the cancer of corruption," and continued by portraying corruption as "a major barrier to sound and equitable development." ${ }^{11}$ In Wolfensohn's vision, anti-corruption efforts were to be part of the "new compact" for development focusing on poverty reduction. In the following year's address, Wolfensohn continued, emphasizing that "corruption, by definition, is exclusive: it promotes the interests of the few over the many. We must fight it wherever we find it," and arguing that the World Bank's (WB's) support to countries should be conditional based on their efforts to address corruption. ${ }^{12}$

I discuss the rise of the anti-corruption narrative over the past 20-30 years by comparing it to the earlier paradigmatic narrative of corporate regulation championed by the UNCTC. I will argue that the UNCTC agenda was surprisingly far-sighted in its analysis of the power of large corporations to plan their internal wealth chains as they wished using secrecy jurisdictions and other conduit countries. The UNCTC approach also stressed the empowerment of governments to regulate the operations of large corporations, with a particular focus on developing countries and transitional economies. In other words, the UNCTC saw corporations as entities that needed to be regulated and states as the legitimate actors for enforcing said regulation, with appropriate support from international agencies.

The anti-corruption agenda provides an interesting contrast to the UNCTC's corporate power agenda, as well as an explanatory framework for the nearly complete devastation of the UNCTC's narrative. While the concept of corruption is old, the anti-corruption agenda only started to take shape around the same time as the UNCTC's decline began - that is, in the late 1970s and early 1980s (even though the issue had been discussed in earlier decades as well). ${ }^{13}$ Correlation does not necessarily imply causality, but it is evident that the anticorruption agenda helped both in exposing the weakest points in the UNCTC's corporate planning framework, and in serving as an ideologically convenient vehicle for shifting the 
blame of global and local economic injustices from the shoulders of large corporations to developing countries. The anti-corruption agenda resonated well with the aims and tools of the structural adjustment programs that the International Monetary Fund (IMF) championed in the $1980 \mathrm{~s}^{14}$, as well as with efforts to deregulate world trade by reducing state control of trade around the world and institutionalizing the new trade regime in supra-national law. ${ }^{15}$ After the focus of the development policy community shifted increasingly from corporate wrongdoings to state failures, it became more natural to focus on states both in attempts to tackle corruption and to promote human rights.

\section{The Corporate Power Framework}

The international development policy agenda started to take shape after the Second World War. The earliest efforts were targeted toward rebuilding war-torn Europe. It was decolonization that turned attention toward how to provide ladders of development to a large group of newly independent countries in the Cold War context. This era also saw the reemergence of international corporate taxation as a major policy issue. ${ }^{16}$ The backbone for these discussions was the international tax regime created in the 1910s, based on background work by the International Chamber of Commerce and enforced by the League of Nations. ${ }^{17}$ This early tax regime aimed at removing double taxation and was based on the separate entity principle. The principle treats all companies belonging to a single enterprise as separate entities, and deems that they should use arm's length prices in their intra-firm transactions. ${ }^{18}$ Arm's length pricing dictates that prices used in intra-firm trade should be same than independent companies would use in their transactions. Only after the issue of doubletaxation had been addressed did the issue of under-taxation that the separate entity principle facilitated become relevant. ${ }^{19}$ 
After the Second World War, the work to abolish double-taxation continued first as an Organization for Economic Development and Cooperation (OECD) -led initiative. ${ }^{20}$ The Paris-based organization advocated a generally more hands-off approach to economic affairs compared to the more Keynesian mainstream ideas of the time. ${ }^{21}$ The work on double taxation reached a major milestone in 1956 when the OECD's Fiscal Committee began elaborating a draft convention to address this concern. The outcome was a document titled "Draft Double Taxation Convention on Income and Capital," adopted in July 1963. To a lesser extent, this convention also addressed the problem of international tax avoidance, proposing that tax administrations should exchange more information on tax matters. ${ }^{22}$

In addition to this, the OECD also discussed tax and development issues in a report titled Fiscal Incentives for Private Investment in Developing Countries. ${ }^{23}$ The report noted that it "is of major importance for a capital importing country to adopt provisions which would keep it from becoming a tax shelter for investors from industrialized countries." ${ }^{24}$ It also pointed to the problems created by "round-tripping," i.e. capital leaving and re-entering countries in the hope of gaining tax benefits. ${ }^{25}$ These issues were also discussed in the United States in Senate hearings and within the Kennedy administration. ${ }^{26}$

Many of the early development theorists saw corruption as a necessary phenomenon that was needed to circumvent bureaucratic regulations in newly independent countries. ${ }^{27}$ This school of thought drew partly from the economic history of the United States, where the gilded era of giant railroad and utility enterprises in the 1870 s and 1880 s was characterized by large-scale corruption and economic growth. ${ }^{28}$ Things began to change at the start of the 1970s, as the corrupting influence of large MNEs began to generate discussion in developing countries and in the UN. ${ }^{29}$ The newly independent countries secured a solid majority within the UN after the World War II, and these former colonies were eager to put forward an 
agenda for changing the terms of the world economy into ones more favorable for them. At the same time, several scandals involving large MNEs emerged in developing countries. ${ }^{30}$

It was the UN, however, that eventually took initiative in analyzing and tackling international corporate tax avoidance. The first strand of this work by the UN originated from the Economic and Social Council resolution 1273 (XLIII) passed on August 1967, which requested that the Secretary-General "set up an ad hoc working group consisting of experts and tax administrators to explore ways and means for facilitating the conclusion of tax treaties between developed and developing countries." 31 The working group consisted of representatives nominated by governments, and it published several reports in the 1970s. The work resulted in the draft model double taxation treaty accompanied by a manual for implementation, first published in $1980 .{ }^{32}$ The UN secretariat then produced a model convention that reproduced the Group's work, which itself was built partially on the double tax convention that the OECD had produced. ${ }^{33}$ Ultimately in 2004, the group was renamed the "Committee of Experts on International Cooperation in Tax Matters" - commonly known as the UN Tax Committee. ${ }^{34}$ Since its inception, the Group stressed many concerns that are familiar from contemporary debates. ${ }^{35}$ In addition to its focus on tax information exchange, the Group addressed many other issues from tax havens to transfer pricing, which was the special focus in the 1975 report. ${ }^{36}$

The second strand arose from the "UN efforts to regulate the operations of transnational corporations and was in part directed to address accounting issues." 37 This process fed into the UN Code of Conduct on Transnational Corporations, which was negotiated over several years but finally abandoned in the early 1990s. ${ }^{38}$ This work began at the 1972 meeting of the Economic and Social Council (ECOSOC), where the Chilean representative called for the UN to appoint a high-ranking expert commission to study the 
role of multinational corporations in developing countries. ${ }^{39}$ The appointment of this commission was ignited by the biggest corporate exposé of the time, namely the U.S. Senate subcommittee report in 1971 that confirmed the involvement of the International Telegraph and Telephone Corporation (ITT) in destabilizing the government of Salvador Allende in Chile. ${ }^{40}$ In 1972, the ECOSOC appointed a 20-member Group of Eminent Persons (GEP), with nine members from the public sector, six from academia, and five from private and public enterprises. ${ }^{41}$ The GEP was mandated to investigate the role of transnational corporations and their impact on the process of development. ${ }^{42}$ In its final report, the GEP recommended establishing a Commission for Transnational Corporations and an Information and Research Center on Transnational Corporations under the ECOSOC. ${ }^{43}$ One year later, the UNCTC began its work as an autonomous center of the UN Secretariat in New York, where it continued to operate until $1993{ }^{44}$

Several sub-groups were then established under the UNCTC, covering many policy areas. One of the key groups was the UN group of accounting experts ("GEISAR") that convened in $1976 .{ }^{45}$ The group made several recommendations in terms of widening corporate financial transparency, and the GEP also made several important policy contributions. ${ }^{46}$ Its 1974 report noted how "advances in communications technology allow many multinational corporations to pursue global strategies which, rather than maximizing the profits or growth of individual affiliates, seek to advance the interest of the enterprise as a whole," helped by a "lack of harmonization of policies among countries, in monetary or tax fields for example," which allows transnationally mobile multinational corporations to "circumvent national policies or render them ineffective." ${ }^{47}$ These developments were facilitated "by corporate planning mechanisms situated in a few industrial countries," 48 resulting in a situation where "the 'invisible hand' of the market is far from the only force guiding economic decisions." 49 
Moreover, the GEP report noted that large corporations have various opportunities for price discrimination and (abusive) transfer pricing. ${ }^{50}$ As a result, "a policy framework which may be adequate for dealing with national corporations needs to be modified when dealing with multinational ones," 51 as state-level attempts to raise taxes "can be negated by vertically or horizontally integrated multinational corporations through transfer pricing and the use of tax havens." 52

A year before the GEP report, the Multinational Corporations in World Development report of the UNCTC also addressed these issues in detail. It noted that the "large incidence of inter-affiliate transactions and attendant transfer pricing can distort the real picture, as can other practices involving capitalization, accounting procedures, and control of local resources." The report argued that this distortion takes place by charging prices for imports that are "far above prevailing 'world' prices, and conversely those for exports have been below world prices." ${ }^{53}$ As a result, "their prices are not determined by the market mechanism but by the corporations themselves." ${ }^{54}$ Several other UNCTC reports put forward similar and surprisingly far-sighted analyses. ${ }^{55}$

Based on the aforementioned analyses, the UNCTC groups made several policy proposals that resemble many of the key initiatives that have been discussed following the 2007-2009 financial crisis in the OECD, UN, and elsewhere. These initiatives included a proposal for increasing mandatory country- and segment-level reporting of key financial figures or large corporations, developing automatic forms of information exchange between tax authorities, promoting unitary taxation, and increasing South-South cooperation on these themes. Due to pressure from the UNCTC and the urge to compete with its proposals, even the often-conservative OECD found itself endorsing quite ambitious reporting recommendations for large corporations, including: the structure of the enterprise, the 
geographical areas where the company operates, sales by geographic area and by major lines of business, significant new capital investments, the sources and uses of funds of the company as a whole, the average number of employees and the R\&D expenditures in each geographical area, the policies followed for intra-group pricing, and the accounting policies. ${ }^{56}$

This history was largely forgotten, however, as the epistemic community around the UNCTC was shattered and the narrative of global development and global economy underwent an overhaul after the Latin American debt crisis began in 1982 and political tides changed. Meanwhile, the United States and other powerful countries had never genuinely embraced the UNCTC, as they preferred continuing work on these themes in the OECD and other agencies where they were in control. I will now turn to a discussion of the anticorruption narrative that to some extent took the place of the earlier corporate planning paradigm, as well as how these two compare.

\section{The Evolution of the Anti-Corruption Narrative}

"Oil companies involved in Angola should ensure that, in Angola and in other countries with similar problems of lack of transparency and government accountability, a policy of 'full transparency' is adopted."

\section{— Crude Awakening, Global Witness 1999}

"Illicit financial flows should not be a human rights concern for States only. While States have the primary duty to respect, protect and fulfil human rights, business enterprises are also required to 'avoid causing or contributing to adverse human rights impacts through their own activities, and address such impacts when they occur' as set out in the Guiding Principles on Business and Human Rights (guiding principle 13)." 
— Illicit financial flows, human rights and the post-2015 development agenda, United Nations General Assembly 2015

In the early 1990s, the international development policy agenda was in disarray. The Cold War was ending, taking with it the ideological competition for the hearts and minds of developing countries' leaders between the Eastern and Western blocs. The Latin American debt crisis and subsequent debt crises had shattered development optimism for much of the Southern world. In industrial policy, import substitution had lost much of its appeal and many countries began to see foreign direct investment as a tool for development. This was accelerated by changes in the world economy, as large companies began to outsource an increasing number of their activities to international value chains and sub-contractors, which challenged the prevailing conceptions of the core and the periphery in the world economy. Finally, all of this was enforced and cemented by the aggressive structural adjustment policies that came with the debt crises and changes in world politics and within the professional economic policy circles. During this intellectual turmoil, the UNCTC and the ideas it had developed lost their appeal and were subsequently largely forgotten. ${ }^{57}$ As a result, the time was ripe in the early 1990s for novel explanations about why people in many developing countries remained in poverty when the economic theories that had undergirded the trade de-regulation and structural adjustment programs promised them prosperity.

The anti-corruption agenda was in many ways a perfect remedy for this situation. First, there was undeniable factual evidence that during the post-colonial decades many newly independent countries had transformed into dictatorships or kleptocratic states where high-ranking officials and politicians reaped the highest benefits. Second, while it was not easy to combine the political factors of corruption with econometric models, this agenda provided a convenient explanation for why the hands-off models of economic governance did 
not deliver the promised benefits. Finally, given that corporate power had become an unfashionable topic, there was simply a vacuum in the international development policy thinking that the anti-corruption agenda filled, at least partially.

There are multiple ways to define corruption, and the subtle —or sometimes overt— differences between them reveal a great deal about the sensitivity and normative nature of this concept. The most classic definition comes from Colin Nye, who maintained that corruption is "behaviour which deviates from the formal duties of a public role because of private-regarding (personal, close family, private clique) pecuniary or status gains; or violates rules against the exercise of certain types of private-regarding influence." ${ }^{\prime 58}$ In his paradigmdefining 1988 book on corruption, Robert Klitgaard argued that, "corruption exists when an individual illicitly puts personal interests above those of the people and ideals he or she is pledged to serve." ${ }^{59}$ While Klitgaard noted that corruption could occur either in private or public sectors, in practice the agenda he was setting shifted the blame for societal problems from private wrongdoings to public failures and embezzlements. In a manner typical of many accounts on corruption, Klitgaard also noted how "what is corrupt in one society may not be in another." ${ }^{90}$ This underlines the normative aspects of any definition given to this term. In the words of Arvind Jain, "how corruption is defined actually ends up determining what gets modeled and measured." 61

In some cases, corruption is even determined in ways that exclude the role and responsibility of the private sector entirely. For example, Toke Aidt defines corruption as the "sale of government property for private gain." 62 It is for good reason, therefore, that Inge Amundsen states that "corruption is understood as everything from the paying of bribes to civil servants in return for some favour and the theft of public purses, to a wide range of dubious economic and political practices in which politicians and bureaucrats enrich 
themselves," or ultimately as "any abusive use of public power to a personal end." ${ }^{\text {" }}$ There is no doubt that part of the pervasiveness and strength of the anti-corruption agenda has arisen at least partly from this vagueness of definition. As a general catch-all category, it is often easy to identify some aspects of corruption in many societal maladies.

Given the prominence of anti-corruption efforts in today's development agenda, it is easy to forget how recently this theme reached its present standing. While corruption-related problems have received a substantial amount of theorizing and empirical research at least since the 1960s, it took a long time before these issues came to international attention. ${ }^{64}$ After Klitgaard tellingly noted in his classic 1988 work, Controlling Corruption, that the literature on international development is "surprisingly silent" about problems caused by corruption, things evolved rapidly. ${ }^{65}$ We need to go back to the history of the Foreign Corrupt Practices Act of the United States in order to understand the evolution of the anti-corruption agenda.

In the late 1970s, there was a growing awareness in the United States that U.S. corporations were engaged in giving bribes to foreign government officials in exchange for procurement contracts or sales commissions. ${ }^{66}$ Driven partly by the attention created by the Watergate scandal, a Special Presidential Task Force began to study the problem in March 1976. The Securities and Exchange Commission (SEC) also conducted a special study on this issue, suggesting that corrupt payments erode public confidence in American business and advocated requirements for more transparent internal auditing. Bills were proposed to tackle the problem and several congressional hearings took place in $1976 .{ }^{67}$

The real breakthrough of anti-corruption efforts into the international agenda took place in the 1990s. The structural adjustment programs of the 1980s had paved way to the "good governance" agenda, and were based on a notion that failures of the public sector lay in the heart of the development failures in Africa. ${ }^{68}$ The initial focus on macroeconomics and 
privatization was gradually extended to cover anti-corruption efforts as well. This development was driven by World Bank, as the IMF was initially reluctant to embrace the broader good governance agenda which it deemed as too political and outside its mandate. This changed in mid-1990s, when the IMF Board of Governors adopted a Declaration on Partnership for Sustainable Global Growth. ${ }^{69}$

A definite milestone were the two speeches given by Wolfensohn, then-President of the WB, in his addresses to the organization's annual meetings in 1996 and 1997, quoted in the introduction to this chapter. By the mid-1990s, anti-corruption had become a major theme in many other forums as well. As often happens, the interest of political scientists and economists followed policy developments. Thus, in 2001, Jain was able to state in his review of corruption literature that the study of corruption had come to an age, "driven by a realisation among international development experts that development requires, above all, good governance." 70

The change of attitude was significant, given the World Bank's hesitancy to address the issue before the emergence of the good governance agenda. ${ }^{71}$ The paradigm change in the World Bank and the IMF reflected a broader international development at that time. The year 1995 marked an important milestone as the non-governmental organization Transparency International (TI) unveiled the first edition of its Corruption Perception Index (CPI), together with the Internet Centre for Corruption Research at the University of Passau. ${ }^{72}$ Soon, the CPI reached definitive status in the corruption measurement business, and it has been a highly influential and much publicized ranking ever since. De Maria has noted that for a long time, CPI has been "unquestionably accepted as a valid and reliable indicator of "corruption" by African governments, donors, media and academia." $" 73$ After TI and the World Bank had 
made their headways into anti-corruption field, the OECD's Anti-Bribery Convention was adopted in 1999, with the UN Convention against Corruption created four years later.

Despite the lip service paid to the role of the private sector in corruption, the great majority of the key analyses and policy initiatives around this subject have focused explicitly on public sector corruption. This can be seen, for example, in Jain's terminology of "bureaucratic corruption" and "legislative corruption." "74 An even more telling example of this phenomenon can be found in the work of Klitgaard. After defining corruption in a way that leaves open the relative importance of the public and private sectors in sustaining corruption, Klitgaard goes on to develop his argument using case studies, devoting most space to discussion of the Philippines. Together with some other countries he discusses more briefly (Mexico, Ghana), this would have offered sufficient material to discuss extensive private sector wrongdoings had Klitgaard chosen to do so, but his focus was elsewhere.

Following the example of these and other scholars, the anti-corruption agenda started to tackle perceived public sector failures. In 2001, this agenda had reached a point where a review of relevant literature could state with confidence that "we now believe that corruption is inimical" to an environment that "stimulates self-sustaining growth and development," and that unsuitable policies are a result of "decision-makers distorting economic policies for their own interest." $" 75$ The result has been "a rapidly growing anti-corruption movement, or ‘industry,' spreading under close western supervision across Africa," which is sometimes detached from the everyday realities of these countries. ${ }^{76}$

Why did the corruption discourse emerge in the 1990s from relative obscurity to rise to prominence in mainstream global development and economic thinking? In 1998, Vito Tanzi noted seven possible explanations. All of them point to the answer that "corruption is 
simply attracting more attention now than in the past," not that there was any significant growth in corruption in quantitative or qualitative terms. ${ }^{77}$

First, Tanzi pointed to the end of the Cold War and the "end of political hypocrisy that had made the decision makers in some industrial countries ignore the political corruption that existed in particular countries." ${ }^{, 78}$ Another aspect of this same phenomenon was highlighted by Baker, Shaxson and Christensen, who noted that it "was considered impolite, as well as unhelpful to certain parochial institutional interests, to delve too deeply into untoward behavior by the elites of newly sovereign and proud countries." 79

Second, according to Tanzi, there had been a reluctance to talk about corruption "by those familiar with these countries, there was also a tendency not to focus on corruption in the centrally planned economies." However, it is also worth noting that in the current world economy characterized by tax competition or tax wars ${ }^{80}$ between nations, there can also be incentives not to focus on corporate malpractices in order to please investors and large foreign corporations. Or, to take an even broader view, political considerations always steer the ways that dominant development narratives are being imposed in development. Third, Tanzi argued that "the increase in recent years in the number of countries with democratic governments and free and active media has created an environment in which discussion of corruption is no longer a taboo." 81

Fourth, Tanzi noted that, "globalization has brought individuals from countries with little corruption into frequent contact with those from countries where corruption is endemic." Fifth, "a growing role has been played by nongovernmental organizations, such as Transparency International, in publicizing the problems of corruption and in trying to create anticorruption movements," and additionally, a "greater reliance on the market for economic decisions and the increased need to be competitive have created an environment in which the 
pursuit of efficiency has acquired greater importance." These two factors can be equally helpful in understanding the rise of the corporate tax avoidance agenda. Finally, Tanzi argues that, "American policymakers have argued that American exporters have lost out in foreign deals because they have not been allowed by law to pay bribes to foreign officials." 82 The broader ideological changes highlighted by Gathii were also undoubtedly a major factor. However, seen from a more historical view, one key explanation was the neglect of any analysis of the role of large corporations in producing development failures.

\section{The Tax Justice Movement and the (Re)emergence of the Corporate Power Agenda}

Today, we have already moved a few steps forward from the situation in the early 2000s when unsuitable policies were seen as a result of "decision-makers distorting economic policies for their own interest. ${ }^{" 83}$ One important — though not very widely known-rupture in this narrative was the 2012 article Hidden trillions: Secrecy, corruption, and the offshore interface by John Christensen, the director of the Tax Justice Network. In his article, Christensen aptly noted that even though corruption discourse had so far "focused predominantly on bribery, or more accurately on bribe-taking by public officials in developing countries and transition economies," corruption also has a supply-side that is "backed by a large infrastructure of financial and legal intermediaries," the majority of which reside in secrecy jurisdictions, more commonly known as tax havens. It is these operators "who provide an interface between illicit activities and the mainstream financial markets." "84

In another article written by Nicholas Shaxson together with Raymond Baker and Christensen, the authors attributed the relative lack of attention to corruption prior to the 1990s to the separation of political economy "into political science and an economics profession, which was driven toward macro approaches in an effort to 'harden' itself 
methodologically" in the post-World War II decades. ${ }^{85}$ According to these authors, the "result was a sharp positivist, quantitative bias that by definition ruled out serious consideration of factors that could not be readily measured - corruption being, almost by definition, such a factor." ${ }^{86}$ While there is probably a significant amount of truth in this, there is another reason for why the anti-corruption agenda emerged in the mid-1990s besides the one put forward by Baker et al. and Tanzi-namely the obfuscation of earlier narratives that focused on corporate power over states.

The critique put forward by Christensen's Tax Justice Network, Global Witness and other actors have had an impact on Transparency International. Transparency International defines corruption as "the abuse of entrusted power for private gain," 87 and lately it has started to see that this power can be private as well. In late 2007, the new head of TI, Cobus de Swardt, told the Financial Times that London and other global financial centers were to expect "much greater pressure" from Swardt's organization, and that "corruption 'facilitated by bankers and financial centers' had received too little attention by the global pressure group," but that this was about to change. ${ }^{88}$ Since then, this "second wave" in the fight against corruption has resulted in various new initiatives. For example, TI has been monitoring the country-by-country level of transparency of large corporations, working on the role of tax systems in facilitating corruption ${ }^{89}$, and reporting on lobbying in Europe..$^{90}$ Despite these laudable initiatives, however, the corruption perception index continues to be the best-known concept of TI, and the definition TI gives corruption on its website is still tilted toward public sector corruption. ${ }^{91}$

The 1990s saw the development of initiatives demanding greater transparency of the tax and other payments made by the extractive industry companies. ${ }^{92}$ One important milestone was achieved in 1999, when an NGO, Global Witness, published a report entitled 
Crude Awakening. The report exposed the complicity of the oil and banking industries in the plundering of state assets during Angola's 30-year civil war. It claimed that the "international oil companies are paying vast sums (the future development potential of Angola) into a black hole" and that "the international oil companies must accept that they are playing with the politics and lives of Angola's people." 93 The report concluded that companies operating in Angola should "publish what they pay" to the government. This led to the establishment of an NGO coalition, Publish What You Pay (PWYP), which called on companies to publish what they paid and governments to publish what they earned as "a necessary first step towards a more accountable system for the management of natural resource revenues."94 Today, the coalition includes more than 800 NGOs around the world. ${ }^{95}$

The public attention generated pressure on intergovernmental organizations. The Extractive Industries Transparency Initiative (EITI) was created by the initiative of the U.K. government in 2002-2003 to foster voluntary reporting on tax payments in the extractive industries. There were mixed motives behind this move. Haufler argued that then U.K. Prime Minister Tony Blair "shifted the focus of the EITI away from company reporting, which is the target of PWYP activism, to reporting and membership by governments." 96 The anticorruption agenda provided a convenient subtext for this resolution. After this decision was made, an EITI secretariat was set up in Oslo as an organization describing itself as "a multistakeholder coalition of governments, companies, investors, civil society organisations, and partner organisations." $" 97$ The EITI requires participating governments to produce “comprehensive EITI Reports that include full government disclosure of extractive industry revenues, and disclosure of all material payments to government by oil, gas and mining companies." 98 The EITI encourages companies to support the initiative and "to promote the Standard internationally and in countries where it operates." 99 Despite its limited scope, PWYP and many other NGOs have been partially supportive of the EITI while continuing to 
criticize its perceived flaws. ${ }^{100}$ At the same time, PWYP continues to campaign for the disclosure of information not covered by the EITI (e.g., mandatory disclosure of the projectlevel payments).

Wójcik noted the importance of the 'initiatives calling for improved transparency in the extractive industries, particularly with regard to payments between corporations and host governments,' behind the calls for that the tax justice movement started to advocate in this millennium, in particular the call for broad country-by-country reporting. ${ }^{101}$ This rising awareness of the problems contributed to the increasing interest in good governance and transparency in the donor community, as demonstrated by the EITI initiative. This concurrent interest in more transparent management and increasing awareness of the problems caused by the resource curse created grounds for demands for increased transparency of the extractive industry revenues.

Today's proposals for broadening the corporate transparency go much further than the EITI's recommendations. After years of intensive civil society campaigning, in 2015 the OECD agreed on a full country-level disclosure of the key financial items of large corporations. This was a major step forward, even though information will be reported only for tax authorities and not for the wider public, and there are other limiting preconditions as well. ${ }^{102}$ In contrast to the earlier focus on prevention of corruption, today’s proposals put more emphasis on enhancing tax compliance and reducing risks associated with nontransparent corporate structures in all industries. The reporting models that tax justice campaigners have been promoting in this millennium would allow informed outside spectators to assess a company's tax aggressiveness and different kinds of risks, among other things, whereas the information provided in the EITI reports does not allow this kind of 
analysis. Today, PWYP also endorses broad country-by-country reporting while continuing to campaign for its original demands. ${ }^{103}$

To recap, the demands for financial transparency in were first fueled by the anticorruption and transparency agenda. Much less attention was paid to the problems created by profit shifting. ${ }^{104}$ This was a natural result in an intellectual environment where corporate power had become an unfashionable topic and there was a vacuum in the international development policy thinking that the more corporate-friendly anti-corruption agenda helped fill. However, when the corporate power narrative returned with the emergence of tax justice campaigning in the early 2000s, this had an impact on the anti-corruption paradigm as well. Consequently, the state-centric initiatives began to look increasingly outdated, and slowly the agenda started to shift in order to accommodate a broader range of concerns. Most importantly, these concerns included the crucial question of how to address the vast powers that large corporations have over developing countries.

\section{Conclusion}

"Taxation is the new frontier for those concerned with state-building in developing countries," Deborah A. Bräutigam argued in the opening words of the book Taxation and State Building in Developing Countries in 2008. Tax issues had just started to gather broader attention within the development community, followed by the scholarly interest. Bräutigam went on to argue that "taxation may play the central role in building and sustaining the power of states, and shaping their ties to society." 105 In addition to the three "Rs" of taxationnamely revenue, redistribution and re-pricing, an important aspect of tax systems is the “fourth R", namely representation, given that well-functioning tax systems foster also statebuilding, human rights agenda and sustaining of democratic societies. ${ }^{106}$ 
However, reducing political corruption in developing countries is not a sufficient condition for creating these kinds of public goods. Rather, many of the same concerns on corporate power and tax flight that were noted in the UN in the 1970s remain unsolved. Any viable agenda on human rights — especially social rights — needs to take seriously the problems created by corporate power over developing countries. In addition to the already discussed problems of tax avoidance, tax evasion, the bargaining power of large corporations over smaller states is also an outcome of structural problems that discourage developing countries from collecting taxes that would be needed for human development. Here, a key problem is international tax competition, or more accurately tax wars ${ }^{107}$ between nations. This international pressure pushes decision makers in developing countries to turn a blind eye to corporate wrongdoings and to offer tax breaks and other sweeteners to large enterprises in exchange for investments. The contrast with the 1970s when developing countries were pushing for major international reforms could hardly be clearer.

What is needed are more comprehensive frameworks for analyzing the reasons behind the obstacles of domestic resource mobilization that pay close attention to both public and private reasons that prevent the fulfillment of social rights and development goals. This would be crucial not only for focusing on the best mix of policy responses to tackle the perceived ills, but also as a guidance for further research on particular topics. To give an example, in hindsight the destruction of the UNCTC was truly a misfortune for the whole international community, even though majority of the policy makers probably did not see it that way back then. Whenever the policy efforts of the international development community become tilted toward one paradigm instead of others, there is a real danger that important viewpoints are neglected completely. 
Even though the human rights impacts of large corporations have received increasing attention in the past years, both practical and theoretical discussions on human rights still largely center on states. As a symptom of this tendency, problems in fulfilling human rights obligations are often discussed in the context of state failures and corrupt regimes. This statecentered approach is also supported by the fact that we apart from a few poorly enforced initiatives, there is a lack of binding human rights obligations for large enterprises. This problem is even more nuanced in the field of corporate taxation, where the OECD's Code of Conduct for Multinational Enterprises is the only guideline that explicitly discusses issues such as transfer pricing. ${ }^{108}$ These guidelines were originally developed as a response to the UNCTC's work on the Code of Conduct for transnational corporations, and the OECD's Code of Conduct has suffered from very weak enforcement even regarding the more traditional environmental and labor concerns. ${ }^{109}$

However, even well intentioned developing country governments may find themselves unable to increase their tax revenues without more stringent international regulation of large enterprises and especially their internal tax and financing arrangements. In order to remedy this situation, there is an urgent need for advances in topical policy proposals such as public country-by-country reporting and unitary taxation. ${ }^{110}$ However, it would also be very helpful to reignite policy and theoretical discussion on establishing an ambitious, binding code of conduct for multinational enterprises, not unlike the one that the UNCTC was working on.

\footnotetext{
${ }^{1}$ M. Hampton and J. Christensen, ' Competing industries in islands: a new tourism approach', 34(4), Annals of Tourism Research (2007).

${ }^{2}$ This part of the chapter relies in many ways on the background work I conducted in my earlier article, see M. Ylönen, 'Back from Oblivion? The Rise and Fall of the Early Initiatives Against Corporate Tax Avoidance from the 1960 s to the 1980 s', (forthcoming).

${ }^{3}$ T.S. Kuhn, The Structure of Scientific Revolutions (1962).

${ }^{4}$ B. Rajagopal, 'Corruption, Legitimacy and Human Rights: The Dialectic of the Relationship', 14 Connecticut Journal of International Law (1999) 495, at 498.
} 


\footnotetext{
${ }^{5}$ Ibid. at $498-499$.

${ }^{6}$ Ibid. at 503

7 Ibid. at 503 .

${ }^{8}$ P. Chowla and T. Falcao, Illicit Financial Flows: concepts and scope (United Nations Financing for

Development Working Paper, December 5, 2016).

${ }^{9}$ B. Schuman, Usual Suspects? Co-conspirators in the business of tax dodging (A Study Commissioned by the Greens/FPA Group in the European Parliament, January 23, 2017).

${ }^{10}$ L. Ndikumana, and J.K. Boyce, New Estimates of Capital Flight from Sub-Saharan African Countries:

Linkages with External Borrowing and Policy Options (Political Economy Research Inistitute PERI Working Paper 16, 2008).

${ }^{11}$ J.D. Wolfensohn, President, World Bank Group, Annual Meeting Address (1 October 1996).

${ }^{12}$ J.D. Wolfensohn, President, World Bank Group, 'The Challenge of Inclusion', Annual Meeting Address (23 September 1997).

${ }^{13}$ Ylönen, supra note 2.

${ }^{14}$ R. Rowden, The Deadly Ideas of Neoliberalism: How the IMF has Undermined Public Health and the Fight Against AIDS (2009),

${ }^{15}$ S. Gill, Power and Resistance in the New World Order (2nd Edition, 2008).

${ }^{16}$ Avi-Yonah, R. S., 'All of a Piece Throughout: The Four Ages of U.S. International Taxation', 25(313) Virginia Tax Review (2005-2006).

${ }^{17}$ T. Rixen, The Political Economy of International Tax Governance (2008), at 88; T. Rixen, 'From Double Tax
} Avoidance to Tax Competition: Explaining the Institutional Trajectory of International Tax Governance', 18(2) Review of International Political Economy (2010) 197.

${ }^{18}$ L. Eden, 'The Arm's Length Standard. Making it work in a 21st-century world of multinationals and Nations States', on Pogge, T. and Mehta, K. (eds.) Global tax fairness (2016), at 153-172.

${ }^{19}$ Rixen, 'From Double Tax Avoidance to Tax Competition', supra note 17.

${ }^{20}$ Rixen, The Political Economy of International Tax Governance, supra note 17, at 48-51; S. Picciotto, International Business Taxation: A Study in the Internationalization of Business Regulation (1992), at 48-51.

${ }^{21}$ R.A. Williams, 'The OECD and Foreign Investment Rules: The Global Promotion of Liberalization', in R. Mahon and S. McBride (eds.), The OECD and Transnational Governance (2008) 117, at 118.

${ }^{22}$ S.S. Surrey, 'United Nations Group of Experts and the Guidelines for Tax Treaties between Developed and Developing Countries', 19(1) Harvard International Law Journal (1978) 1; Rixen, The Political Economy of International Tax Governance, supra note 17.

${ }^{23}$ OECD, Fiscal Incentives for Private Investment in Developing Countries (1964).

${ }^{24}$ Ibid.

${ }^{25}$ Ibid. at 55 .

${ }^{26}$ Rixen,, 'From Double Tax Avoidance to Tax Competition', supra note 17, at 17; G.D. Webster, 'Current Developments in Federal Income Taxation', 29(3) Tennessee Law Review (1962) 419.

${ }^{27}$ N.H. Leff, 'Economic Development Through Bureaucratic Corruption', 8(3) American Behavioral Scientist (1964) 8, 8-14; J.S. Nye, 'Corruption and Political Development: A Cost-Benefit Analysis', 61(2) American Political Science Review (1967) 417, 419-420; S.P. Huntington. Political Order in Changing Societies (1968), at 69.

${ }^{28}$ J.T. Gathii, 'Defining the Relationship between Human Rights and Corruption', 31(1) University of Pennsylvania Journal of International Law (2009) 125, at 136.

${ }^{29}$ Ibid. at 127.

${ }^{30}$ Ibid. at 138.

${ }^{31}$ Ylönen, supra note 2.

${ }^{32}$ For a historical review, see B. Kosters, ' The United Nations Model Tax Convention and Its Recent Developments', Asia-Pacific Tax Bulletin January- February (2004)

${ }^{33}$ Ylönen, supra note 2; Surrey, supra note 22.

${ }^{34}$ T. Rixen, The Political Economy of International Tax Governance, supra note 17, at 147-148; Ylönen, supra note 2 .

${ }^{35}$ United Nations, Tax Treaties Between Developed and Developing Countries (1969); United Nations, Tax Treaties Between Developed and Developing Countries: Second Report (1970); United Nations, Tax Treaties 
Between Developed and Developing Countries: Third Report (1972); United Nations, Tax Treaties Between Developed and Developing Countries: Fourth Report (1973); United Nations, The Impact of Multinational Corporations on Development and on International Relations (1974); United Nations, Tax Treaties Between Developed and Developing Countries: Fifth Report (1975); United Nations, Tax Treaties Between Developed and Developing Countries: Sixth Report (1976); United Nations, Tax Treaties Between Developed and Developing Countries: Seventh Report (1978); United Nations, Manual for the negotiation of bilateral tax treaties between developed and developing countries (1979); Ylönen, supra note 2.

${ }^{36}$ United Nations, Tax Treaties Between Developed and Developing Countries: Fifth Report, supra note 35.

${ }^{37}$ Ylönen, supra note 2.

${ }^{38}$ Ibid.

${ }^{39}$ S.F. Rahman, 'International Accounting Regulation by the United Nations: A Power Perspective', 11(5) Accounting, Auditing \& Accountability Journal (1998) 593; T Sagafi-Nejad, J.H. Dunning and H.V. Perlmutter, The UN and Transnational Corporations: From Code of Conduct to Global Compact (2008); Ylönen, supra note 2 .

${ }^{40}$ K. Hamdani and L. Ruffing, United Nations Centre on Transnational Corporations: Corporate Conduct and the Public Interest (2015); Rahman, supra note 39, at 595; Sagafi-Nejad et al, supra note 39, at 42-43.

${ }^{41}$ Sagafi-Nejad et al, supra note 39, at 57.

${ }^{42}$ ECOSOC, Resolutions. Supplement No. 1 (E/5209, Fifty-third session, 3-28 July 1972), at 4.

43 The UN Department of Economic and Social Affairs prepared a background report titled 'Multinational Corporations in Development' in 1973 for the GEP. Many of the recommendations and analyses of the GEP group drew heavily from this 1973 report. See Hamdani and Ruffing, supra note 40, Rahman, supra note 39, at 599; Sagafi-Nejad et al, supra note 39, at 59.

${ }^{44}$ Sagafi-Nejad et al, supra note 39, at 6; K.P. Sauvant, 'The Negotiations of the United Nations Code of Conduct on Transnational Corporations: Experience and Lessons Learned', 16(1) The Journal of World Investment and Trade (2015) 11.

${ }^{45}$ In addition, a Working Group on the Code of Conduct was created under the UNCTC. See Rahman, supra note 39; Sauvant, supra note 44, at 20.

46 Ylönen, supra note 2.

${ }^{47}$ UN 1974 supra note 35 , at 30.

${ }^{48}$ Ibid. at 30.

49 Ibid. at 41.

${ }^{50}$ Ibid. at 30.

51 Ibid. at 31 .

52 Ibid. at 35.

${ }^{53}$ Ibid. at 32.

54 Ibid. at 33.

55 Ylönen, supra note 2.

${ }^{56}$ S.S. Surrey, 'Reflections on the Allocation of Income and Expenses among National Tax Jurisdictions', 10 Law \& Policy in International Business (1978) 409, at 434-435.

57 Ylönen, supra note 2.

${ }^{58}$ Quoted in I. Amundsen, Political Corruption: Introduction to the Issues (1999), at 2.

${ }^{59}$ R. Klitgaard, Controlling Corruption (1991), at xi.

${ }^{60}$ Ibid.

${ }^{61}$ A.K. Jain, 'Corruption: A Review’, 15(1) Journal of Economic Surveys (2001) 71, at 73.

62 T.S. Aidt, 'Corruption, Institutions, and Economic Development', 25(2) Oxford Review of Economic Policy (2008) 271.

${ }^{63}$ Amundsen, supra note 58, at 1.

${ }^{64}$ Ibid. at 1.

${ }^{65}$ Klitgaard, supra note 59, at 6.

${ }^{66}$ Gathii, supra note 28, at 141.

${ }^{67}$ Gathii, supra note 28, at 142. 
${ }^{68}$ Supra note 14 , at 75 .

${ }^{69}$ Gathii, supra note 28, at 145.

${ }^{70}$ Jain, supra note 61 , at 71 .

${ }^{71}$ R. Baker, N. Shaxson and J. Christensen, 'Catching up with Corruption', 4(1) The American Interest (2008) 65.

72 J.G. Labsdorff, ' Measuring the dark side of human nature: The birth of the Corruption Perceptions Index', Internet Centre for Corruption Research, available at http://www.icgg.org/corruption.cpi_childhooddays.html (last visited 10 July 2017).

${ }^{73}$ W. De Maria, 'Measurements and Markets: Deconstructing the Corruption Perception Index' 21(7) International Journal of Public Sector Management (2008) 777, at 778.

74 Jain, supra note 61.

75 Ibid. at 71.

${ }^{76}$ De Maria, supra note 73, at 778.

77 V. Tanzi, ' Corruption Around the World: Causes, Consequences, Scope, and Cures' 45(4) IMF Staff Papers (1998) 559, at 560.

78 Tanzi, supra note 77 , at 560

${ }^{79}$ Baker et al, supra note 71.

80 J. Christensen and N. Shaxson, 'Tax Competitiveness - A Dangerous Obsession', in T. Pogge and K. Mehta (eds.), Global Tax Fairness (2016) 265.

${ }^{81}$ Tanzi, supra note 77 , at 560 .

82 Ibid. at 561.

${ }^{83}$ Jain, supra note 61 , at 71

${ }^{84}$ J. Christensen, 'The Hidden Trillions: Secrecy, Corruption, and the Offshore Interface', 57(3) Crime, Law \& Social Change (2012) 325, at 326.

85 Baker et al, supra note 71.

86 Baker et al, supra note 71.

87 Transparency International, What is Corruption? (2017), available online at https://www.transparency.org/what-is-corruption/ (last visited 10 July 2017).

${ }^{88}$ H. Williamson, 'Anti-Graft Watchdog to Step up Pressure On West', Financial Times, 15 November 2007.

${ }^{89}$ M. Hearson, Tax Systems: A Channel for Corruption or a Way to Fight It? (Transparency International Working Paper No. 3, 2015).

${ }^{90}$ S. Mulcahy, Lobbying in Europe: Hidden Influence, Privileged Access (2015), available online at https://www.transparency.org/whatwedo/publication/lobbying_in_europe (last visited 12 June 2017).

${ }^{91}$ Interestingly, the rationale of Transparency International could be used verbatim to describe the agenda put forward by the UNCTC as well: 'Corruption is one of the greatest challenges of the contemporary world. It undermines good government, fundamentally distorts public policy, leads to the misallocation of resources, harms the private sector and private sector development and particularly hurts the poor. Controlling it is only possible with the cooperation of a wide range of stakeholders in the integrity system, including most importantly the state, civil society, and the private sector. There is also a crucial role to be played by international institutions' (Transparency International, Mission Statement, available online at http://transparency.org.au/index.php/about-us/mission-statement/ (last visited 12 June 2017)). This speaks volumes about the paradigmatic nature of both the corruption narrative and the narrative of corporate planning. Neither narrative alone can explain the great challenges the states and the international community have been facing and still continue to face in modern times, but one thing is for certain: neglect of either state or corporate failures will lead into tilted policies and unsatisfactory outcomes.

92 A. Christians, 'Tax Activists and the Global Movement for Development Through Transparency' (2012), available online at http://papers.ssrn.com/abstract=2029055, at 3 (last visited 12 June 2017).

${ }^{93}$ Global Witness, A Crude Awakening: The Role of the Oil and Banking Industries in Angola's Civil War and the Plunder of State Assets (1999), available online at https://www.globalwitness.org/sites/default/files/pdfs/A\%20Crude\%20Awakening.pdf, at 2 (last visited 12 June 2017).

${ }^{94}$ Publish What You Pay, History, available online at http://www.publishwhatyoupay.no/en/about-pwypnorway/history/history (last visited 10 July 2017). 
${ }^{95}$ Publish What You Pay, About Us, available online at http://www.publishwhatyoupay.org/about (last visited 12 June 2017).

${ }^{96} \mathrm{~V}$. Haufler, 'Disclosure as Governance: The Extractive Industries Transparency Initiative and Resource Management in the Developing World', 10(3) Global Environmental Politics (2009) 53, at 65.

${ }^{97}$ Extractive Industries Transparency Initiative (EITI), Stakeholders, available online at https://eiti.org/supporters (last visited 12 June 2017).

${ }^{98}$ EITI, EITI Factsheet 2017 (2017) Extractive Industries Transparency Initiative [

${ }^{99}$ Ibid.

${ }^{100}$ S. Gallhofer and J. Haslam, 'Exploring Social, Political and Economic Dimensions of Accounting in the Global Context: The International Accounting Standards Board and Accounting Disaggregation', 5(4) SocioEconomic Review (2007) 633, at 649; Haufler, supra note 96, at 66.

${ }^{101}$ D. Wójcik, 'Shining Light on Globalization: The Political Economy of Country-By-Country Reporting' (2012), available online at https://papers.ssrn.com/sol3/papers.cfm?abstract_id=2163449, at 6 (last visited 12 June 2017).

${ }^{102}$ Financial Transparency Coalition, OECD Country-by-Country Reporting: Only for the Strong?, 17 September 2015, available online at https://financialtransparency.org/oecd-country-by-country-reporting-onlyfor-the-strong/ (last visited 12 June 2017).

${ }^{103}$ Publish Whay You Pay, Extended country-by-country reporting. The 3-minute version, available online at http://www.publishwhatyoupay.org/pwyp-resources/extended-country-by-country-reporting-the-3-minuteversion/ (last visited 10 July 2017).

${ }^{104}$ Haufler, supra note 96, at 54.

105 D. Bräutigam, 'Introduction: taxation and state-building in developing countries' in D. Bräutigam, O.H. Fjeldstad and M. Moore (eds.), Taxation and State Building in Developing Countries (2008)

106 Tax Justice Network, The Four "Rs", 09 July 2007, available online at http://taxjustice.blogspot.com/2007/07/four-rs.html (last visited 11 July 2017).

${ }^{107}$ Christensen and Shaxson, supra note 80 at 265.

${ }^{108}$ International Bar Association, Tax Abuses, Poverty and Human RightsA report of the International Bar Association's Human Rights Institute Task Forceon Illicit Financial Flows, Poverty and Human Rights (October 2013).

${ }^{109}$ OECD Watch, Remedy Remains Rare: An analysis of 15 years of NCP cases and their contribution to improve access to remedy for victims of corporate misconduct (June 2015).

${ }^{110}$ S. Picciotto, 'Towards Unitary Taxation', in T. Pogge and K. Mehta (eds.) Global Tax Fairness (2016) 221237); R. Murphy, 'Country-by-Country Reporting', in T. Pogge and K. Mehta (eds) Global Tax Fairness (2016) $96-112$. 